Brigham Young University Law School

BYU Law Digital Commons

Faculty Scholarship

3-1-2012

\title{
Transnational Armed Conflict: A “Principled” Approach to the Regulation of Counter-Terror Combat Operations
}

\author{
Geoffery S. Corn \\ South Texas College of Law, gcorn@stcl.edu \\ Eric Talbot Jensen \\ BYU Law, jensene@law.byu.edu
}

Follow this and additional works at: https://digitalcommons.law.byu.edu/faculty_scholarship

Part of the Military, War, and Peace Commons, and the Terrorism Studies Commons

\section{Recommended Citation}

Geoffery S. Corn \& Eric Talbot Jensen, Transnational Armed Conflict: A "Principled" Approach to the Regulation of Counter-Terror Combat Operations, 42 ISR. L. REV. 46 (2012).

(C) Cambridge University Press and The Faculty of Law, The Hebrew University of Jerusalem 2009 This Article is brought to you for free and open access by BYU Law Digital Commons. It has been accepted for inclusion in Faculty Scholarship by an authorized administrator of BYU Law Digital Commons. For more information, please contact hunterlawlibrary@byu.edu. 


\title{
Transnational Armed Conflict: A "Principled" Approach to the Regulation of Counter-Terror Combat Operations
}

\author{
Geoffrey Corn* \& Eric Talbot Jensen**
}

Transnational armed conflicts have become a reality. The increasing sophistication of terrorist organizations, their increasingly transnational nature, and their development of military strike capabilities, push and will continue to push States to resort to combat power as a means to defend against this threat. Relying on the factual fiction that the acts of such terrorists must be attributable to the States from which they launch their operations, or on the legal fiction that the use of military combat power to respond to such threats is in reality just extraterritorial law enforcement, fails to acknowledge the essential nature of such operations. Because these operations invoke the authority of the LOAC, they should and must be treated as armed conflicts.

LOAC principles must be identified and must be broad enough to provide the authority necessary to bring the transnational enemy to submission while ensuring that that authority does not override fundamental humanitarian protections for victims of war. This Article proposes three essential pillars of this regulatory foundation: military necessity, targeting (object/distinction and proportionality), and humane treatment. These principles provide the balance between authority and obligation that is so essential for the effective and disciplined application of combat power. Like the treatment of internal armed conflict, these pillars can form a foundation for a more comprehensive treatment of regulatory analysis, encompassing other issues such as command responsibility, criminal liability, access to judicial review, perfidy and treachery, and medical obligations.

\footnotetext{
- Associate Professor of Law at South Texas College of Law. Previously served as the Special Assistant to the U.S. Army JAG for Law of War Matters; Chief of the Law of War Branch, U.S. JAG General International and Operational Law Division; the U.S. Army JAG Corps from 1992-2004; supervisory defense counsel for the Western United States; Chief of International Law for U.S. Army Europe; and professor International and National Security Law, the U.S. Army JAG School.

- Lieutenant Colonel, Chief, International Law Branch, U.S. Army, JAG; Operational Law Attorney, Task Force Eagle, Bosnia, 1996; Command Judge Advocate, Task Force Able Sentry, Macedonia, 1997; Chief Military Law, Task Force Eagle, Bosnia, 1998; professor, International and Operational Law Department, JAG Legal Center and School, 2001-2004. Deputy Staff Judge Advocate, 1st Cavalry Division, Baghdad, Iraq, 2004-2005.

The views expressed in this Article are those of the authors and not those of the JAG Corps, the U.S. Army, or the U.S. Department of Defense.
} 


\section{INTRODUCTION}

Article $3 \ldots$ provides that in a 'conflict not of an international character occurring in the territory of one of the High Contracting Parties, each Party to the conflict shall be bound to apply, as a minimum,' certain provisions protecting '[p]ersons taking no active part in the hostilities, including members of armed forces who have laid down their arms and those placed hors de combat by ... detention.'

Common Article 3, then, is applicable here....2

With these words, the United States Supreme Court invalidated the military commissions created by President Bush. ${ }^{3}$ However, of far greater significance for purposes of conflict regulation, the Court concluded that the protections of Common Article $3^{4}$

' Hamdan v. Rumsfeld, 548 U.S. 557, 629-30 (2006).

${ }^{2} I d$. at 631 .

${ }^{3}$ Id. at 634 .

${ }^{4}$ The provision is referred to as "Common" Article 3 because it is found identically in each of the four Geneva Conventions. Common Article 3 states:

Art 3. In the case of armed conflict not of an international character occurring in the territory of one of the High Contracting Parties, each Party to the conflict shall be bound to apply, as a minimum, the following provisions:

(1) Persons taking no active part in the hostilities, including members of armed forces who have laid down their arms and those placed hors de combat by sickness, wounds, detention, or any other cause, shall in all circumstances be treated humanely, without any adverse distinction founded on race, colour, religion or faith, sex, birth or wealth, or any other similar criteria. To this end the following acts are and shall remain prohibited at any time and in any place whatsoever with respect to the abovementioned persons:

(a) violence to life and person, in particular murder of all kinds, mutilation, cruel treatment and torture;

(b) taking of hostages;

(c) outrages upon personal dignity, in particular, humiliating and degrading treatment;

(d) the passing of sentences and the carrying out of executions without previous judgment pronounced by a regularly constituted court affording all the judicial guarantees which are recognized as indispensable by civilized peoples.

(2) The wounded and sick shall be collected and cared for. An impartial humanitarian body, such as the International Committee of the Red Cross, may offer its services to the Parties to the conflict. The Parties to the conflict should further endeavour to bring into force, by means of special agreements, all or part of the other provisions of the present Convention. 
apply to all armed conflicts. ${ }^{5}$ In so holding, the Court applied the "literal meaning" of the terms of this treaty provision, thereby mandating humane treatment toward any person detained in the context of a non-international armed conflict, irrespective of the geographic scope of that conflict.

The decision by the Court to endorse this broad application of Common Article 3 was unsurprising to many observers, ${ }^{7}$ even though it was a clear repudiation of the interpretation of this article adopted by President Bush and his administration. ${ }^{8}$ Indeed, the Bush administration had consistently asserted that Common Article 3 did not apply to detainees in the Global War on Terror. ${ }^{9}$ Nonetheless, once the Hamdan decision was announced, the administration acted quickly to confirm that all detainees, regardless of their status, were entitled to the protections of Common Article $3 .^{10}$ To this end, the Department of Defense promulgated a new manual on interrogation "that mandated application of Common Article 3 to all Department of Defense detainees. ${ }^{12}$ The administration also put forward legislation that confirmed Common Article 3 as

The application of the preceding provisions shall not affect the legal status of the Parties to the conflict.

Id.

'See Hamdan v. Rumsfeld, supra note 1, at 631 n.63; see also Helen Duffy, The War on Terror and the Framework of International Law 227 (2005).

${ }^{6}$ Hamdan v. Rumsfeld, supra note 1, at 630.

7 Sean D. Murphy, Evolving Geneva Convention Paradigms in the "War on Terrorism": Applying the Core Rules to the Release of Persons Deemed "Unprivileged Belligerents," 75 Geo. Wash. L. REv 1105, 1148 (2007).

${ }^{8}$ See Mr. John Bellinger, State Department Briefing (Oct. 19, 2006) available at LEXIS, News File; See Day to Day: What's Behind Bush's Push to Redefine Common Article 3?, (National Public Radio broadcast Sept. 20, 2006); Memorandum from Jay S. Bybee, Assistant Attorney General, U.S. Department of Justice, to Albert R. Gonzalez, Attorney General, \& William J. Hughes II, General Counsel, Department of Defense (Jan. 22, 2002); Hearing on the Authority to Prosecute Terrorists Under The War Crime Provisions of Title 18 Before the S. Comm. on the Judiciary, 109th Cong. 46 (2006) (Statement of Steven Bradbury, Acting Assistant Attorney General of the Office of Legal Counsel, Department of Justice).

${ }^{9}$ See generally David E. Graham, The Treatment and Interrogation of Prisoners of War and Detainees, 37 Geo. J. INT'L L. 61 (2005).

${ }^{10}$ Gordon England, Deputy, Office of the Secretary of Defense, Memo: Application of Common Article 3 of the Geneva Conventions to the Treatment of Detainees in the Department of Defense (July 7, 2006), available at http://www.fas.org/sgp/othergov/dod/geneva070606.pdf; Charles Babington \& Michael Abromowitz, Bowing to Justices, Administration Says It Will Apply Treaties to Terror Suspects, WASH. POST, at Al (July 12, 2006), available at http:/www.washingtonpost.com/wp-dyn/ content/article/2006/07/11/AR2006071100094.html.

"U.S. Dep'T of the Army, Field Manual 2-22.3 Human Intelligence Collector Operations (2006).

${ }^{12}$ Id. para. 5-74. 
the baseline standard of protection for all persons detained during armed conflict ${ }^{13}$ and delineated the specific violations of this article that were serious enough ${ }^{14}$ to be violations of the War Crimes Act-the U.S. domestic statute establishing criminal jurisdiction over the commission of war crimes. ${ }^{15}$

This intersection of judicial interpretation of the LOAC and the Bush administration response is significant on multiple levels. But perhaps the greatest significance lies in the implied recognition of a relatively unconventional theory of armed conflict manifested by this course of events: a clear acceptance by the Supreme Court of the government's assertion that Hamdan was detained in the course of an armed conflict. ${ }^{16}$ When coupled with the Bush administration's subsequent acknowledgment that Common Article 3 applies to all individuals detained by the U.S. armed forces, there can be little doubt that the United States accepts the applicability of the LOAC to an armed conflict with a transnational non-State actor, namely al Qaeda. ${ }^{17}$ In a very real sense, this course of events simply aligned the legal and practical position of the United States, for there is even less doubt that the United States responded to the terror attacks of September $11^{\text {th }}$ (and perhaps even prior to that date ${ }^{18}$ ) by invoking armed conflict authorities.

However, as the authors have noted previously, ${ }^{19}$ applying Common Article 3 to transnational armed conflicts is not sufficient to effectively regulate the conduct

\footnotetext{
${ }^{13}$ Military Commissions Act of $2006 \S 948 b(a)$, 10 U.S.C. $\S 948 b(a)$ (2006).

${ }^{14}$ War Crimes Act of 1996, 18 U.S.C. § 2441(d) (2006).

${ }^{15}$ Military Commissions Act of $2006 \S 6,18$ U.S.C. § 2441(c)(3) (2006).

${ }^{16}$ Hamdan v. Rumsfeld, supra note 1, at 629.

${ }^{17}$ One common critique of the transnational armed conflict proposal is that it somehow invites or legitimizes the conduct of military operations against non-State transnational enemies. As the authors have argued elsewhere (see Geoffrey S. Corn \& Eric T. Jensen, Untying the Gordian Knot: A Proposal for Determining Applicability of the Laws of War to the War on Terror, Temple L. Rev. (forthcoming), available at http://ssm.com/abstract=1083849), we do not believe this to be the case. Instead, we accept the inevitability of the authorization of such military operations, and seek only to establish a triggering mechanism to ensure that when a State employs its armed forces in such a capacity, those forces are bound by a regulatory framework that matches the fundamental nature of the authority invoked by the State. Accordingly, acknowledging applicability of fundamental LOAC principles to include the principle of military necessity, will ensure not that the State is empowered to take measures it deems necessary to address the transnational threat-a given in the view of the authors-but that the power invoked by the State is limited consistently with the nature of that principle as it has evolved.

${ }^{18}$ See United States v. Hamdan, Ruling on Defense Motion for a Bill of Particulars, June 3, 2008 (indicating that "the Government has repeatedly declared that its theory at trial will be that the armed conflict between the United States and al Qaeda/bin Laden began not later than 1996"), available at http://www.defenselink.mil/news/D-036\%20For\%20Bill.pdf.

${ }^{19}$ Corn \& Jensen, supra note 17.
} 
of hostilities between State armed forces and non-State transnational enemies. The mandate of Common Article 3 addresses only the treatment of detainees and other individuals rendered hors de combat. It is axiomatic that there remains a wide array of battlefield conduct that does not implicate such treatment decisions, and that military forces will engage in hostilities prior to subduing opposition forces and subjecting them to detention. This uncertainty implicates the most basic elements of such conflicts-the legality of target engagement, detention, status, and treatment of participants. This Article argues that military operations conducted by a State against a transnational non-State enemy do, under certain circumstances, trigger the application of fundamental LOAC principles that dictate resolution of these issues.

In so doing, the Article raises what the authors believe is an interesting amalgam of lex lata and lex ferenda. The notion of transnational armed conflict represents an evolution of the law, more properly characterized as lex ferenda than lex lata. However, it is the premise of the authors that the imperative that "no battlefield go unregulated" renders the application of fundamental LOAC principles to this emerging category of armed conflict as much in the realm of lex lata as lex ferenda.

At the outset of this Article, the authors feel compelled to note that they do not believe or intend to suggest the need to create a "new paradigm" for application of the LOAC. Instead, while the term "transnational" armed conflict (TAC) may be new, the substantive impact of this concept is, the authors believe, a very old paradigm - that armed forces carry norms of conduct with them during all combat operations. In other words, a State cannot invoke the authorities of armed conflict and not concurrently accept the obligations. Accordingly, the use of the term "transnational" is really just semantic; what the authors believe is significant is that armed conflict must be understood as triggering the normative framework of the LOAC. And that is a proposition that the authors believe is really as old as organized warfare itself.

Part I of this Article briefly discusses the traditional distinction between Common Article 2 and Common Article 3 conflicts, and the effect of the Hamdan decision and its statement of applicability of Common Article 3 to all armed conflicts that are not between Nation-States. Part II proposes specific principles necessary to form the foundation for any armed conflict regulation. These include the principles of military necessity, principles regulating the targeting of opposition personnel, and the principle of humane treatment as it relates to the status and treatment of captured personnel. The Article concludes by noting that it is only the first step in what needs to be a full discussion concerning the application of LOAC principles to TAC. However, as this discussion takes place, it must be anchored in the idea that the authorities 
granted through the application of LOAC principles must always be accompanied by the corresponding obligations.

\section{Common Article 2, Common Article 3, and Hamdan}

At the outset of its opinion in Hamdan v. Rumsfeld, the Supreme Court noted that the "[Petitioner] concedes that a court-martial constituted in accordance with the Uniform Code of Military Justice ... would have authority to try him."20 This seemingly innocuous acknowledgment held profound significance, for it indicated an underlying concession that Hamdan's conduct occurred in the context of an armed conflict and was regulated by the LOAC. No other meaning can be derived from this language, because pursuant to Article 18 of the Uniform Code of Military Justice, court-martial jurisdiction over Hamdan could only exist as a result of a violation of the laws of war. ${ }^{21}$ This was critical to the Court's subsequent analysis of Common Article 3, for it allowed the Court to bypass the predicate question of whether the struggle against al Qaeda qualified as an armed conflict.

Of course, the fact that the Petitioner seemed to concede the issue of the existence of armed conflict did not prohibit the Court from addressing that question. Indeed, several amici challenged this premise. That the Court accepted this concession with no critical scrutiny seems to indicate that all members of the Court believed that they were indeed analyzing the exercise of power related to an armed conflict within the meaning of international law. This was at the time and remains a fairly controversial interpretation of the law of non-international armed conflict, given that many scholars and experts insist that the latter is synonymous with purely internal armed conflict, ${ }^{22}$ or

${ }^{20}$ Hamdan v. Rumsfeld, supra note 1, at 567.

${ }^{21} 10$ U.S.C. \$ 818; see also Major Jan E. Aldykiewicz \& Major Geoffrey S. Corn, Authority to Court Martial Non-U.S. Military Personnel for Serious Violations of International Humanitarian Law Committed During Internal Armed Conflicts, 167 MiL. L. Rev. 74 (2001).

${ }^{22}$ For example, the International Committee of the Red Cross website provides the following explanation of the two types of armed conflicts:

International humanitarian law distinguishes between international and non-international armed conflict.

International armed conflicts are those in which at least two States are involved. They are subject to a wide range of rules, including those set out in the four Geneva Conventions and Additional Protocol $\mathbf{I}$.

Non-international armed conflicts are those restricted to the territory of a single State, involving either regular armed forces fighting groups of armed dissidents, or armed groups fighting each other. A more limited range of rules apply to internal armed conflicts and are 
that operations conducted against transnational terrorist groups are not armed conflicts at all. ${ }^{23}$ However, as the authors have asserted in previous articles, ${ }^{24}$ based on the nature of the military response chosen by the United States to destroy or disable al Qaeda, this "armed conflict" characterization of the military component of the struggle against transnational terror networks is not only justified but reflects a legitimate recognition of what is best understood as transnational armed conflict-an "internationalized" noninternational armed conflict, triggering LOAC authorities and obligations.

Because the Court accepted this premise, it then became necessary to determine what law, if any, was triggered by the conflict in which Hamdan committed his alleged crimes. This in turn required the Court to deal head on with the interpretation of the LOAC that had formed the foundation for all of the Bush administration's wartime policies. This interpretation essentially disavowed obligations imposed by the law while at the same time invoking its authority to support wartime actions. While a majority of the Court ultimately rejected this "sweet without the bitter" approach, understanding why they did so is essential to understanding why Parties to such conflicts must apply a more comprehensive "package" of LOAC principles to transnational armed conflicts.

As noted above, the Hamdan Court apparently concluded that the critical question for determining applicability of LOAC obligations was whether the United States was engaged in an armed conflict against al Qaeda, and not the geographic scope of the conflict. While this may seem logically unremarkable-that applicability

laid down in Article 3 common to the four Geneva Conventions as well as in Additional Protocol II.

See International Committee of the Red Cross, What is International Humanitarian Law, Advisory Service on International Humanitarian Law, (07/2004), available at http://www.icrc.org/Web/eng/ siteeng0.nsf/iwpList 104/707D6551B17F0910C1256B66005B30B3. This interpretation of the LOAC is also reflected in the United Kingdom Ministry of Defense, Law of Armed Conflict Manual, which indicates:

The law of armed conflict applies in all situations when the armed forces of a state are in conflict with those of another state or are in occupation of territory. The law also applies to hostilities in which some of those involved are acting under the authority of the United Nations and in internal armed conflicts. Different rules apply to these different situations.

See United Kingdom Ministry of Defence, The Manual for the Law of Armed Conflict para. 3.1 (2004) (emphasis added G.C. \& E.T.J.).

${ }^{23}$ See, e.g., Rosa Ehrenriech Brooks, War Everywhere: Human Rights, National Security, and the Law of Armed Conflict in the Age of Terrorism, 153 U. PenN. L. Rev. 675 (2004).

${ }^{24}$ See Corn \& Jensen, supra note 17; see also Geoffrey Corn, Hamdan, Lebanon, and the Regulation of Armed Conflict: The Need to Recognize a Hybrid Category of Armed Conflict, 40 Vand. J. Transnat'l L. 295 (2007). 
of the law of war should turn on the existence of armed conflict-it was anything but. Accordingly, the Court confronted an anomaly produced by application of this conventional LOAC triggering paradigm. The Bush administration unquestionably considered the struggle against al Qaeda as an armed conflict; indeed, the entire Military Commission concept was premised on the existence of this armed conflict. ${ }^{25}$ Ironically, it was the Geneva Conventions that provided the basis for this anomaly. The "triggering" articles of these treaties-Common Articles 2 and $3^{26}$ - had evolved to be regarded as the definitive criteria for determining applicability of the LOCA. And these articles require satisfaction of one of two alternative geographic scope requirements.

To trigger the full corpus of the Geneva Conventions, Common Article 2 required that the armed conflict be "international" within the meaning of the treaty. ${ }^{27}$ This in turn required the conflict to be inter-state. In contrast, Common Article 3 provided for a baseline standard of humane treatment for the victims of armed conflicts "not of an international character." 28 However, that term had historically been understood to mean intra-state conflicts, essentially the modern day analogue of civil war. This narrow meaning of "not of an international character" was reflected in the text of Common Article $3{ }^{29}$ the International Committee of the Red Cross Commentary, ${ }^{30}$ and the Final Record of the drafting conferences. ${ }^{31}$ It was also confirmed decades later when APII came into force. ${ }^{32}$ The most simplistic explanation for the Bush administration's policies was, therefore, that the conflict against al Qaeda fell into a "twilight zone" between these two types of armed conflict: because al Qaeda was a non-State entity, the conflict was not "international" within the meaning of Common Article 2; but because the conflict was essentially global in nature, it was not "noninternational" pursuant to the accepted meaning of Common Article 3.

The Hamdan majority ultimately rejected this interpretation of the Geneva Convention law triggering articles, holding that Common Article 3 operated in

\footnotetext{
${ }^{25}$ President George Bush, Memo: Humane Treatment of al Qaeda and Taliban Detainees (Feb. 7, 2002), available at http://www 1.umn.edu/humanrts/OathBetrayed/Bush\%202-7-02.pdf.

${ }^{26} \mathrm{GCI}$, art. 2-3; GCII, art. 2-3; GCIII, art. 2-3, GCIV, art. 2-3.

${ }^{27} \mathrm{GCI}$, art. 2, ("the present Convention shall apply to all cases of declared war or of any other armed conflict which may arise between two or more of the High Contracting Parties...").

${ }^{28}$ Id. at art. 3 ("In the case of armed conflict not of an international character ...").

${ }^{29} \mathrm{Id}$. ("occurring in the territory of one of the High Contracting Parties...").

30 Jean Pictet et. al., Commentary on the Geneva Conventions of 12 August 1949. Vol. I $42-43$ (1952) [hereinafter GCI COMMENTARY]

${ }^{31}$ Final Record of the Diplomatic Conference of Geneva of 1949 (1950-51).

${ }^{32}$ APII, art. 1.
} 
"contradistinction" to Common Article 2.33 This holding, coming from the highest court in the land, established the controlling interpretation of Common Article 3 for the United States, requiring U.S. practitioners to assume that all armed conflicts not satisfying the requirements of Common Article 2 are, ipso facto, non-international within the meaning of Common Article 3.

The Court's reasons for adopting this interpretation seem twofold. First, the Supreme Court could hardly have denied the existence of an armed conflict between the United States and al Qaeda. Not only had the Petitioner implicitly conceded such a state of affairs, but the record clearly established that both the President and Congress had invoked the war powers of the nation in response to the terror attacks of September 11 th. ${ }^{34}$ This then leads to the second reason for the interpretation: Recognizing that the President had invoked the authority of the law of war, the Court was seemingly unwilling to allow for the exercise of that authority without compliance with the most fundamental obligations of the law, specifically the humane treatment mandate of Common Article 3. ${ }^{35}$ From a conflict regulation perspective, the true significance of the Hamdan decision was therefore the restoration of the balance between authority and obligation, a balance that had been distorted by the Bush administration, but one that the Court apparently recognized lies at the core of the LOAC.

This restoration produced its own uncertainty-what LOAC rules or "principles" apply to these conflicts of "contradistinction" from international armed conflicts? The complexity of this question is highlighted by a simple reality: The vast majority of LOAC codification that occurred in the twentieth century was focused on international rather than non-international armed conflicts. For the Hamdan Court, this was a relatively insignificant consideration, for the rule of decision they were addressing was one of the few rules developed specifically for non-international conflicts: Common Article 3. However, by endorsing this new LOAC application paradigm, the decision led to the inevitable question of what rules beyond Common Article 3 are also applicable to non-international, or perhaps more specifically, transnational armed conflicts.

Fortunately, from an analytical perspective, responding to this question has been facilitated by the relatively recent developments in the law applicable to noninternational armed conflict. Beginning with the landmark Tadic decision of the

\footnotetext{
${ }^{33}$ Hamdan v. Rumsfeld, supra note 1, at 630.

${ }^{34} I d$. at 594.

${ }^{35} \mathrm{Id}$. at 629-35.
} 
International Criminal Tribunal for the Former Yugoslavia (ICTY) ${ }^{36}$ there has been a growing recognition among the international legal community of the need to define with greater precision the regulatory framework applicable to such conflicts. ${ }^{37}$ Because much of this development has taken place within the context of criminal prosecutions, it was necessary to determine the legally binding nature of this regulatory framework. In this regard, the Tadic Tribunal initiated this process; it concluded that a number of fundamental principles developed to regulate international armed conflicts had made, in the language of the Tribunal, a "gradual extension" into the realm of noninternational armed conflicts. ${ }^{38}$ In so doing, the judgment acknowledged that there had not been a wholesale transplant from one realm of conflict to the other, but instead emphasized the fundamental nature of the core principles applicable as a matter of custom to both types of armed conflict. ${ }^{39}$

It is the thesis of this Article that extending this process of determining the fundamental principles of the law applicable to both international and internal armed conflicts to the realm of transnational armed conflicts reflects a logical and necessary evolution of the law. However, it is clear that determining the scope of regulation of armed conflicts that defy traditional Common Article 2/Common Article 3 characterization is almost as difficult a task as developing a theory of law applicability to such armed conflicts. Indeed, the most common critiques of the theory of transnational armed conflict we have proposed have fallen into two categories. ${ }^{40}$ The first is to challenge the validity of the proposal of a category of armed conflict extending beyond the traditional inter/intra-state paradigm on the basis that the LOAC applies only to international or internal armed conflicts. ${ }^{41}$ The second is that even conceding such a category of armed conflict should be recognized, how can it be determined what rules operate to regulate such conflicts? ${ }^{42}$ The first critique has

\footnotetext{
${ }^{36}$ Prosecutor v. Tadić, Case No. IT-94-1-A, Appeal Chamber (July 15, 1999).

${ }^{37}$ See Monica Hakimi, International Standards for Detaining Terrorism Suspects: Moving Beyond the Armed Conflict-Criminal Divide, 33 YALE J. INT'L L. 369 (2008).

${ }^{38}$ Prosecutor v. Tadić, Case No. IT-94-1-A, Decision on the Defence Motion for Interlocutory Appeal on Jurisdiction, paras. 116, 119 (Oct. 2, 1995); see also Anthony Cullen, Key Developments Affecting the Scope of Internal Armed Conflict in International Humanitarian Law, 183 MiL. L. Rev. 66 (2005) (providing an excellent analysis of the significance of the Tadić ruling).

${ }^{39}$ Id. paras. 126-27.

${ }^{40}$ These critiques have been expressed by other experts in the field in two recent symposia: one sponsored by The Hebrew University Minerva Center for Human Rights in Jerusalem (June 2008), the other at the Naval War College in Newport, Rhode Island (July 2008).

${ }^{41}$ See supra note 21 and accompanying text.

${ }^{42}$ For example, during a recent symposium addressing LOAC applicability to the conflict in Afghanistan, Professor Yoram Dinstein criticized the validity of a transnational armed conflict (TAC)
} 
been answered in our previous articles. The second, we believe, is answered by this Article.

Accordingly, what have been described elsewhere as the fundamental principles of the LOAC come into force whenever military operations conducted against transnational non-State enemies rise to the level of armed conflicts. This is not to suggest that this is or should be the exclusive source of regulation for such conflicts. Instead, this anticipates a process similar to that which has illuminated the body of regulation applicable to internal armed conflicts. Indeed, it was this spirit that obviously animated the development of the recently published San Remo Manual on the law of non-international armed conflicts. ${ }^{43}$ This Manual, written by three highly respected LOAC scholars and practitioners and built on the Tadić foundation, provided a much more comprehensive analysis of the content of the law that regulates non-international armed conflicts. Like the Tadic Tribunal, the Manual's authors limited their proposed rules to core LOAC principles. ${ }^{44}$ While they explicitly limited its applicability to internal armed conflicts, their logic of relying on core LOAC principles to add the proverbial flesh to the bones of the Tadic framework seems to provide a model for identifying the content of a regulatory framework for transnational armed conflicts.

The necessary starting point in the development of consensus on the rules applicable to transnational armed conflict is to emulate the Tadic/San Remo approach to the regulation of internal armed conflicts; and again, what is most significant about the methodology used in both these examples is that the scope of the rules determined to be applicable to this category of armed conflict went well beyond the humane treatment mandate of Common Article 3 invoked by the Hamdan Court. In addition to this foundational principle, both these authorities included within that scope a range of principles derived from both the Geneva and Hague traditions. ${ }^{45}$ This expanded scope is not only logical, it is essential, for armed conflicts require regulation not only of the treatment of individuals who are hors de combat, but also of the application of combat power.

theory because, inter alia, there was no viable method of assessing the principles applicable to such conflicts. Comments of Professor Yoram Dinstein, Naval War College Workshop: "The War in Afghanistan: A Legal Analysis" (July 2008).

${ }^{43}$ Michael N. Schmitt, Charles H.B. Garraway \& Yoram Dinstein, The Manual on the Law of Non-International Armed Conflict With Commentary (2006) [hereinafter NiAC Manual].

${ }^{44}$ Id. at $18-45$.

${ }^{45}$ Tadić case, supra note 38, paras. $111,118 \& 120$; NIAC Manual, supra note 43, paras. 1.2.21.2.3, 2.1.1.4. 


\section{The Principles Applicable to Transnational Armed Conflict}

The basic principles of the [law of international armed conflict] are beyond dispute. The principle of distinction (between combatants and civilians), the principle of causing no unnecessary suffering to combatants, the principle of proportionality in attack, etc., are elevated to the pinnacle of law regulating the conduct of hostilities in international armed conflict. However, as one descends from fundamentals to specifics, consensus shrinks. ${ }^{46}$

\section{A. Military Necessity: The First Principle of Authority \\ "The authority to kill implies the authority to detain" 47}

This statement was made by the Judge Advocate General of the Canadian Armed Forces during a conference addressing legal issues related to the conflict in Afghanistan. It was in response to a routine question that arose during that conference: "what is the legal basis for detentions in Afghanistan." The General's simple response to this question reveals, in the opinion of the authors, an invocation of the most fundamental principle of the LOAC: the principle of military necessity. This statement reflects the premise that detention of an opposition fighter, an individual subject to being killed pursuant to the LOAC, is a necessary incident of war. Accordingly, the authority to detain need not be traced to a statutory grant, or a UN mandate, or a specific LOAC treaty provision. Instead, the authority is derived from the basic authority granted by the LOAC to take those measures necessary to bring about the prompt submission of an enemy, in short, from the principle of military necessity.

The principle of military necessity is considered by some LOAC scholars as a core principle of jus in bello. ${ }^{48}$ This is not surprising, considering the principle is reflected in some of the foundational conventions of the law. ${ }^{49}$ However, the concept of military necessity has recently fallen into what might best be described as a state of

46 Yoram Dinstein, The Conduct of Hostilities under the Law of International ARmed Conflict 255 (2004).

${ }^{47}$ Statement by Brigadier General Kenneth Watkin, Judge Advocate General for the Canadian Defense Forces, made in July 2008 during a symposium held at the Naval War College in Newport Rhode Island.

${ }^{48}$ A.P.V. Rogers, Law on the Battlefield 3 (2nd ed. 2004); Michael J. Davidson, War and the Doubtful Soldier, 19 Notre Dame J.L. Ethics \& Pub. Pol'y 91, 153 (2005); Olugbenga Shoyele, Armed Conflicts and Canadian Refugee and Law Policy, 16 INT'L J. Refugee L. 547, 555 (2004).

${ }^{49}$ See Rogers, supra note 48 , at 4-5. 
dormancy, with some experts questioning whether the principle remains viable and relevant in contemporary LOAC. ${ }^{50}$ These experts contend that the previous effect of military necessity has been subsumed in specific provisions of the conventional law of war, thereby dispensing with the need or justification to assert a continued independent role for military necessity. Whether such an interpretation of the law is legitimate in the context of international armed conflict is debatable, but beyond the scope of this Article. It does however seem that the justification for such an interpretation relies on the applicability of the full corpus of the law applicable to international armed conflicts. Because transnational armed conflicts are not, like their international counterparts, governed by the full corpus of the law, this contention is inapplicable to these conflicts. In fact, it is precisely because of the lack of comprehensive conventional regulation applicable to this realm of conflict that it is essential to consider the force and effect of military necessity as a core principle for their regulation. ${ }^{51}$

The predominant reason why States characterize the struggle against transnational terror as an armed conflict is to invoke the fundamental authorities of war, or, the principle of military necessity. And, because the authority to detect, destroy, or disable terrorist capabilities is the essential byproduct of invoking the LOAC, an authority primarily derived from the principle of military necessity, such an invocation requires adherence to the regulatory constraints established by the same source of law. It is the principle of military necessity that establishes this essential balance between obligation and authority.

This balance results from the fact that the authority derived from the contemporary principle of military necessity is not absolute. Although prior to September 11 th this proposition might have seemed axiomatic to virtually all LOAC scholars and

\footnotetext{
${ }^{50}$ INGRID DeTtER, THE LAW OF WAR 394 (2nd ed. 2000) ("There is great difficulty in reconciling any humanitarian rules of warfare with 'military necessity'.... The elusive blanket phrase 'military necessity' may undermine any advances made in the humanitarian field since, again, it is a matter for the subjective assessment of the State whether such necessity exists.").

${ }^{51}$ This reality has been reflected in several opinions of the U.S. Supreme Court dealing with the wartime powers of the President in relation to detained enemy combatants. Although not using the term "military necessity," the Court has repeatedly characterized the detention of enemy combatants as a "necessary incident of war." This characterization is an obvious synonym for the principle of military necessity. Unable to cite to a specific provision of the conventional law of war authorizing the detention of enemies captured in the context of a non-international armed conflict, the Court has fallen back on the first principle of authority for wartime actions: the necessity derived from the state of conflict itself
} 
practitioners, the LOAC interpretations that provided the foundation for the Bush administration's war on terror policies challenged this premise. These interpretations invoked military necessity as a source of legal authority to take any measure necessary for accomplishing the strategic goal of defeating al Qaeda, ${ }^{52}$ and notoriously failed to acknowledge that the principle of necessity had evolved in a manner inconsistent with such an interpretation. The principle of military necessity-is premised on a balance between authority and obligation that lies at the LOAC's core. This balance is reflected in the definition of military necessity found in the U.S. Army Field Manual 27-10, The Law of Land Warfare:

The law of war... requires that belligerents refrain from employing any kind or degree of violence which is not actually necessary for military purposes and that they conduct hostilities with regard for the principles of humanity and chivalry. The prohibitory effect of the law of war is not minimized by "military necessity" which has been defined as that principle which justifies those measures not forbidden by international law which are indispensable for securing the complete submission of the enemy as soon as possible. ${ }^{53}$

Military necessity is therefore the international legal link between lawful military objectives and the actions taken to achieve those objectives. This legal link is intended to limit the destructive actions of combatants to only those that contribute to achieving the military objective of bringing the enemy to submission. The concept of imposing such limitations on combatants is arguably as ancient as organized warfare itself, and reflects the ultimate logic of warfare, which is to prevent the necessity of war from becoming a justification for the infliction of suffering beyond that which is needed to secure a military victory, a concept reflected in Napoleon's great maxim: "in politics and war alike, [that] every injury done to the enemy, even though permitted by the rules, is excusable only so far as it is absolutely necessary; everything beyond that is criminal."

${ }^{52}$ Such as employing destructive combat power against al Qaeda operatives in the territory of a neutral country, see CBS News, U.S. Strikes Somalia Reportedly Killing 31, Jan. 9, 2007, available at http://www.cbsnews.com/stories/2007/01/08/world/main2335451.shtml; see also Eric Schmitt \& Mark Mazzetti, Classified Order Allows U.S. to Attack al Qaeda Worldwide, INT'L HeRALD TRIBUNE, Nov. 10, 2008, available at http://www.iht.com/articles/2008/11/10/ mideast/terror.php.

${ }^{53}$ U.S. Dep't of ARmy, Field Manual 27-10, The Law of Land 3-4 (July 1956) [hereinafter FM 27-10]. 
The adoption of a balanced definition of military necessity by professional armed forces in the decades following the decisions of the post-World War II, International military tribunals bolsters the conclusion that the limiting effect of the principle has become both immutable and indisputable. However, as noted above, the uncertainty related to the law applicable to TAC allowed the Bush administration to invoke the authority of necessity while simultaneously disavowing the complementary principle of humanity. ${ }^{54}$

This episode reinforces why it is so critical to acknowledge the applicability of the contemporary principle of military necessity to TAC. This principle provides essential authority to employ the means necessary to bring a transnational non-State enemy to submission, to include detaining captured enemy operatives for so long as they continue to pose a threat of returning to the fight. However, the principle also provides an essential constraint on the authority of the State, and mandates application of the balancing principles of humane treatment and the prohibition of employing measures calculated to inflict unnecessary suffering. ${ }^{55}$ As a result, it reinforces the

\footnotetext{
${ }^{54}$ See, e.g., Charles A. Flint, Challenging the Legality of Section 106 of the USA PATRIOT Act, 67 ALb. L. REv. 1183 (2004).

${ }^{55}$ As noted in the preceding section, TAC raises a particular difficult dilemma caused by the intersection of the inherent need to identify groups who are subject to targeting and the unconventional nature of transnational non-state enemies. Developing a theory of targeting based on the notion of "fighters" is one step in the solution of this dilemma. However, because there will always be increased uncertainty as to the combatant character of members of such groups as compared with that of regular armed forces, it is essential to ensure compliance with principles intended to limit the harm inflicted on such personnel to only that amount that is necessary. It is because of this that the principle prohibiting the infliction of unnecessary suffering takes on added relevance in the regulation of TAC. The LOAC requires a balance between destruction and humanity not only where noncombatants are concerned, but even when applying violence to an enemy force. In the practice of the armed forces of the United States, this balance arguably takes two forms, one well accepted, and the other less apparent. It is well accepted that this principle limits the use of weapons or ammunition calculated to cause superfluous injury or suffering, FM 27-10, supra note 53, and there is no plausible reason why this prohibition is not completely applicable to any armed conflict. Indeed, linking the legality of weapons to the nature of an armed conflict would not only be illogical, it would be operationally confusing and inefficient. The principle of preventing unnecessary suffering is found in FM 27-10, and based on the express language of Hague IV, which in Article 23 states: "It is especially forbidden ... to employ arms, projectiles, or other materiel calculated to cause unnecessary suffering." GCIV, art. 23. FM 27-10 interprets this provision as follows:
}

What weapons cause "unnecessary injury" can only be determined in light of the practice of States in refraining from the use of a given weapon because it is believed to have that effect . . . Usage has, however, established the illegality of the use of .... irregular-shaped bullets, and projectiles filled with glass, the use of any substance on bullets that would tend unnecessarily to inflame a wound inflicted by them, and the scoring of the surface or the filing off of the hard cases of bullets. 
inherent balance between authority and obligation that lies at the core of the law of war, a balance that is integrally connected to legitimate and effective military operations, including the targeting of individuals and objects.

\section{B. Targeting of Persons and Property}

It is a simple reality of warfare that in order to defeat an enemy it is necessary to attack and destroy the enemy's combat capability. Employment of combat power

FM 27-10, supra note 53, at 18, para. 53. A less obvious application of this principle is to limit the degree of suffering inflicted on lawful objects of attack to only that which is necessary to bring about the submission of the enemy. It is, perhaps, the most obvious example of the "desire to diminish the evils of war," Id. at 3, which, according to U.S. Army Field Manual 27-10, is the fundamental purpose of the law of war: "The conduct of armed hostilities on land is regulated by the law of land warfare which is both written and unwritten. It is inspired by the desire to diminish the evils of war by: a. Protecting both combatants and noncombatants from unnecessary suffering." Id.

Relying on this principle to limit the amount of suffering inflicted upon enemy combatants (or fighters) to only that which is necessary to achieve the enemy's submission is thoroughly consistent with the concept of military necessity. It is military necessity that justifies inflicting suffering upon an enemy combatant. $I d$. at 4 . But as noted above, nations have historically recognized that military necessity justifies inflicting only as much suffering as is necessary to force the enemy to submit. Id. It is also thoroughly consistent with the FM 27-10 "purpose statement" for the law of war quoted above, which identifies the prevention of unnecessary suffering of noncombatants, and the restoration of peace, as key components of the purpose of the law of war. $I d$. at 3 . Prohibiting the infliction of suffering upon enemy forces which cannot be justified as "necessary" for the purpose of bringing about their submission serves both these ends. Of course, the standard for determining what is necessary suffering inflicted on an enemy that has not yet been brought to submission must be more permissive than the standard related to protecting non-combatants. Therefore, this rule should not be read to prohibit a military force from assaulting a lawful military objective with "overwhelming" force. The principle does, however, suggest that there is some limit to the amount of force that can lawfully be brought to bear against a military objective, even if the exact determination of when force exceeds such limits is undefined. Thus, with regard to enemy combatants, the principle prohibiting the infliction of unnecessary suffering is, as A.P.V. Rogers notes, a "brake" on the scope of suffering that may legitimately be inflicted by warriors even when directed at each other.

Whether in the form of prohibiting the employment of weapons which cause unnecessary suffering, or prohibiting the application of force which cannot be considered necessary to subdue an enemy, the principle of preventing unnecessary suffering has obvious applicability to TAC. This principle is at the core of the LOAC, and there is absolutely no logical reason why it should not be applied to such conflicts. In fact, the relationship between preventing unnecessary suffering and mission legitimacy is arguably more pronounced during these type operations than during international armed conflict. This is because the very nature of these conflicts raises troubling questions related to the status of non-State actors. Accordingly, a principle that results in restraint in the means used to attack these personnel will contribute to the overall perception of legitimate military operations. 
for this purpose is referred to in the lexicon of military operations as targeting. The targeting process involves identifying a military objective; selecting the most appropriate capability ${ }^{56}$ to achieve the desired operational effect (often referred to as weaponeering), ${ }^{57}$ executing military operations to employ the combat capability; and assessing the effects achieved. Executing such operations within the bounds of the LOAC is undoubtedly challenging in any operational context. However, in the context of transnational armed conflict, this challenge is exacerbated by the uncertainty regarding the boundaries of military objective and the unconventional nature of the non-State enemy. It is therefore critical to identify and embrace a meaningful and effective regulatory framework for targeting operations in this context.

The percentage of civilian casualties injured during armed conflict has risen from $19 \%$ in World War I to $48 \%$ in World War II and to $90 \%$ in the armed conflicts of the $1990 \mathrm{~s}^{58}$ While there are undoubtedly numerous reasons for these statistics, it is interesting to note that concurrent with this increase in risk to those not directly involved in combat has been a dramatic increase in technological advancement of weaponry and in the codification of rules on how to employ those weapons. Ironically, the purpose of both these advances has included mitigation of the risk of harming innocent civilians and their property. But in order for these developments to have their intended effect, it is first necessary to identify the line between legitimate objects of attack and those people, places, and things that are immune from attack. To accomplish this, the LOAC evolved to establish three general categories of individuals on the battlefield: combatants, non-combatants, and civilians. Combatants are those persons who meet the criteria of GCIII art. 4A(1), (2), (3), or (6). ${ }^{59}$ Non-combatants

${ }^{56}$ This includes kinetic or non-kinetic capability. For example, a commander may employ a conventional kinetic munition to target an enemy capability, or may choose to employ a non-kinetic capability, such as information, to achieve the desired effect.

${ }^{57}$ This concept is referred to as "effects based targeting." It involves tailoring the application of combat power to the stated operational effect desired, which could include destroying, disabling, disrupting, or harassing an enemy.

${ }^{58}$ Ronald R. Lett, Olive Chifefe Kobusingye, \& Paul Ekwaru, Burden of Injury During the Complex Political Emergency in Northern Uganda, 49 CAN. J. SURGERY 1, 51 (2006), available at http://www.cma.ca/multimedia/staticContent/HTML/N0/12/cjs/vol-49/issue-1/pdf/pg51.pdf.

${ }^{59} \mathrm{GCIII}$, art. 4A reads:

A. Prisoners of War, in the sense of the present Convention, are persons belonging to one of the following categories, who have fallen into the power of the enemy:

(1) Members of the armed forces of a Party to the conflict as well as members of militias or volunteer corps forming part of such armed forces. 
include medical personnel and chaplains who are authorized to be on the battlefield and cannot be attacked, but lose their protections if they engage in combat acts. ${ }^{60}$ All other persons are classified as civilians ${ }^{61}$ and benefit from presumptive immunity from being made the object of attack. This immunity is subject to divestment, ${ }^{62}$ but only if the civilian directly participates in hostilities. ${ }^{63}$ The rule that affects this immunity and accordingly prohibits combatants from targeting civilians or civilian objects is known as the principle of distinction and is considered a foundational principle of the law of war. ${ }^{64}$

There is virtually no dispute within the international community, including the armed forces regulated by the LOAC, that civilians are and must remain immune from attack. Neither is there a dispute that the legitimate needs of an armed force justify divesting civilians of this immunity when, as the result of their conduct, they participate directly in hostilities. However, as with many law of war rules, the proverbial devil is in the details. Specifically, determining what conduct in what type of conflict results in a divestment of civilian immunity has been one of the most elusive issues in the development of the law.

(2) Members of other militias and members of other volunteer corps, including those of organized resistance movements, belonging to a Party to the conflict and operating in or outside their own territory, even if this territory is occupied, provided that such militias or volunteer corps, including such organized resistance movements, fulfill the following conditions:

(a) that of being commanded by a person responsible for his subordinates;

(b) that of having a fixed distinctive sign recognizable at a distance;

(c) that of carrying arms openly;

(d) that of conducting their operations in accordance with the laws and customs of war.

(3) Members of regular armed forces who profess allegiance to a government or an authority not recognized by the Detaining Power.

(6) Inhabitants of a non-occupied territory, who on the approach of the enemy spontaneously take up arms to resist the invading forces, without having had time to form themselves into regular armed units, provided they carry arms openly and respect the laws and customs of war.

${ }^{60} \mathrm{API}$, art. 43 , para. 2.

${ }^{61} I d$. art. 50, para. 1.

${ }^{62} I d$. art. 51 , para. 3.

${ }^{53}$ Id.

64 NIAC Manual, supra note 43, at 10 (quoting Protocol I \& II Commentary); Rogers, supra note 48, at 3 ("The great principles of customary law, from which all else stems, are those of military necessity, humanity, distinction and proportionality.'). 
In Tadic, the appellate chamber opined that the principle of distinction was so fundamental to the conduct of hostilities that it applied equally to all armed conflicts. ${ }^{65}$ The NIAC Manual embraces this interpretation and states that it is "indisputable that the principle of distinction is customary international law for both international

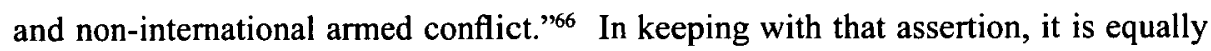
"indisputable" that the applicability of the principle of distinction to transnational armed conflict should be acknowledged. However, as with non-international armed conflict, the difficulty arises when defining what actions by civilians make them targetable, particularly in an environment where one side to the armed conflict is presumably composed completely of civilians participating in hostilities.

In such a case, it seems utterly illogical to suggest that outside the context of international armed conflict, there is no such thing as an "enemy" for purposes of targeting, but only civilians who temporarily lose their immunity by virtue of taking a direct part in hostilities. Such a conception is fundamentally inconsistent with the history of non-international armed conflicts, which routinely involved organized opposition groups treated by government forces just as much an "enemy" as the armed forces of opposing States during international armed conflicts. However, the concept of TAC produces a further complicating factor: Unlike traditional "internal" armed conflicts, "organization" is not necessarily a condition precedent to the existence of such armed conflicts. Indeed, the TAC proposition is based in large part on the assumption that transnational non-State entities will often defy any notion of traditional military "organization." As a result, determining what members of such organizations are the lawful objects of attack based on an armed conflict theory is particularly challenging.

The NIAC Manual addressed this difficult but critical issue by using the nontraditional term of "fighters" to describe participants in a non-international armed conflict who are either "members of armed forces and dissident armed forces or other organized armed groups, or taking active (direct) part in hostilities." Manual asserts that "[A]ttacks must be directed only against fighters or military objectives." and conventional international law and concludes, in agreement with Tadić, that the targeting principles--including distinction and proportionality-apply to regulate both

\footnotetext{
${ }^{65}$ Tadić case, supra note 38, paras. 102-04.

${ }^{66}$ NIAC Manual, supra note 43, para. 1.2.2.3.

${ }^{67} \mathrm{Id}$. para. 1.1.2.a.

${ }^{68}$ Id. para. 2.1.1.
} 
international and non-international armed conflict. Other emerging approaches to this non-State actor targeting dilemma appear to reinforce the approach adopted by the Manual. These include the concept "Likely and Identifiable Threat" currently being used in Afghanistan by Coalition forces for identifying individuals subject to "status"based targeting 69 and the concept of the "revolving door" of direct participation in hostilities recently endorsed by the $\mathrm{HCJ}$ in the Targeted Killing decision. ${ }^{70}$ Both these approaches share a common element: They establish criteria whereby association with a hostile group justifies designating an individual as a lawful military objective irrespective of the individual's conduct at the time of targeting.

Concluding that the targeting principles apply to TAC is, however, only the first step in the regulatory process. The much more difficult question is determining who is the object of lawful attack in such a context. If military operations against transnational terrorist entities are conceived purely as a form of extraterritorial law enforcement, the answer to this question would arguably be dictated by a human rights paradigm, essentially allowing the use of deadly force only in self defense when no lesser means of "subduing" the opponent is feasible. This is not, however, how such operations are conceptualized by States or the armed forces operating on their behalf. Instead, because the threshold of armed conflict against transnational non-State enemies is crossed when armed forces operate pursuant to status-based rules of engagement, these operations defy a law enforcement characterization. Accordingly, it would be fundamentally inconsistent with the implicit invocation of the targeting authority of the LOAC to limit the lawful objects of attack to only those individuals posing a direct and imminent threat or those causing actual harm. ${ }^{71}$

A nation's authorization of status-based rules of engagement is a signal that there are opposing forces who can be engaged upon sight, thus implicating the LOAC. In a previous article, the authors wrote "a nation's adoption of status-based rules

${ }^{69}$ InT'l \& Operational Law Dep't, The Judge Advocate General's School, U.S. Army, Operational Law HandBook 86 (MAJ John Rawcliffe ed., 2007) ("b. Declared Hostile Force. Any civilian, paramilitary or military force or terrorist that has been declared hostile by appropriate U.S. authority. Once a force is declared to be 'hostile,' U.S. units may engage it without observing a hostile act or demonstration of hostile intent; i.e., the basis for engagement shifts from conduct to status."); Center for Law and Military Operations, The Judge Advocate General's Legal Center \& School, U.S. Army, Legal Lessons Learned From Afghanistan and Iraq Volume I Major Combat Operations (Sept. 11, 2001-May 1, 2003) 312 (1 Aug. 2004) (sample ROE card for Operation Iraqi Freedom).

${ }^{70} \mathrm{HCJ} 769 / 02$ The Public Committee Against Torture in Israel v. The Government of Israel [Dec. 14, 2006] (unpublished), at para. 40.

71 Yves Sandoz, et al., Commentary on the Additional Protocols of 8 June 1977 to the Geneva Conventions of 12 August 1949 para. 1942 (1987) [hereinafter Protocol I \& II Commentary]. 
of engagement for its military in a particular military operation should constitute the trigger requiring that nation and its military to apply the laws of war to that operation." 72 The authors continued, "because status-based ROE require no justification for the use of force beyond threat recognition and identification, they indicate that the State views the nature of the military mission as sufficient to trigger the targeting authority of the laws of war." 73 The above analysis clarifies which targeting rules must apply and confirms the prior thesis that when using military forces in a TAC, those forces must adhere to the time-honored principles of targeting such as distinction and proportionality. This is true because the battlefield will, by definition, be a broad mix of civilians, some of whom will retain their status and others of who will forfeit theirs, not only based on a single act, but also based on a pattern of actions and affiliations that create a nexus sufficient to a non-temporary forfeit of civilian protections.

Application of targeting principles to TAC therefore necessitates a broader scope of targeting authority than merely responding to civilians who take a direct part in hostilities. It requires some methodology to distinguish individuals justifiably immune from attack by virtue of their abstention from any participation in hostilities from those individuals who, by virtue of their connection with and conduct in support of an armed hostile group, are justifiably characterized as lawful objects of attack as the result of being part of an enemy force. As noted above, this notion that non-State actors can, as the result of such factors, be best understood as "fighters" is not novel, and is central to the treatment of targeting in the NIAC Manual. The principles of targeting necessary to preserve the principle of distinction equally apply for those civilians who are acting as "fighters," This point was reinforced by Human Rights Watch, who condemned Hezbollah for launching cluster attacks that "were at best indiscriminate, i.e., they violated the principle of distinction by using unguided and highly inaccurate cluster munition models against populated areas. At worst, Hezbollah deliberately attacked civilian areas with these weapons." 74

The continuing efforts by LOAC experts, the ICRC, and judicial bodies to address this issue of how to characterize groups of fighters such as Hezbollah, and the continued movement toward some recognition that these non-State entities can evolve into some type of quasi-“combatant" force for targeting purposes, indicate

\footnotetext{
${ }^{72}$ Corn \& Jensen, supra note 17 , at 5.

73 Id. at 57.

${ }^{74}$ See Lebanon/lsrael: Hezbollah Hit Israel with Cluster Munitions during Conflict, available at http://hrw.org/english/docs/2006/10/1 8/lebano14412.htm (last visited Apr. 1, 2009).
} 
the need to acknowledge that such characterization is inherent in combat operations launched against such groups. ${ }^{75}$ In the context of TAC, whatever standard is devised for designating opposition groups subject to targeting, that standard must be consistent with the underlying purposes of the LOAC. Any State invoking the authority of the principle of military objective in order to attack a non-State enemy must ensure that the complementary targeting principles of proportionality and minimization of civilian risk are also applied. Here again, the utility of a rules of engagement analytical focus becomes clear. Once a military commander is authorized to engage an opponent with combat power based solely on a determination of the status of that opponent (irrespective of the status determination criteria), that commander must understand his obligation to comply with the principles of the LOAC that operate to limit the suffering resulting from the application of that combat power. This is the core of the proposal offered here: that a "package" of LOAC targeting principles must be applicable to TAC for the simple reason that failing to acknowledge such applicability will open the door to the implied invocation of the authority to employ combat power without the complementary limitations on that authority.

A part of the package of LOAC targeting principles that apply to TAC is the principle of proportionality. The principle of proportionality prohibits attacks which "may be expected to cause incidental loss of civilian life, injury to civilians, damage to civilian objects, or a combination thereof, which would be excessive in relation to the concrete and direct military advantage anticipated."76 The NIAC Manual provides an excellent explanation of the terms and meaning of proportionality ${ }^{77}$ that need not be repeated here, except to say that the same reasoning applies to the principle of proportionality in TAC.

It is important to highlight two additional points in relation to the application of proportionality in TAC. First, due to the nature of the fighters and the fact that they are civilians who are either part of armed groups or persons taking part in hostilities, the proportionality analysis must reflect the reality of the situation. By participating

${ }^{75}$ But see Ronald Reagan, The U.S. Decision Not to Ratify Protocol I to the Geneva Conventions on the Protection of War Victims: Letter of Transmittal, 81 AM. J. INT'L L. 910, 911 (1987).

${ }^{76}$ Although this "proportionality" test is used in API to define the meaning of an indiscriminate attack, see API, art. 51(5)(b); and as a component of the Article 57 precautions in the attack obligations, see id. at art. 57(2)(a) and (b), it is a "stand-alone" provision in FM 27-10, which, in paragraph 41 , indicates that ". . . loss of life and damage to property incidental to attacks must not be excessive in relation to the concrete and direct military advantage to be gained." FM 27-10, supra note 53 , at 5 .

${ }^{77}$ NIAC Manual, supra note 43, para. 2.1.1.4. 
in hostilities, these civilians have surrendered the protections they would otherwise be granted. Therefore, when a commander conducts his proportionality analysis, he need not account for the civilians who are fighters, but must then apply the principle as he would under API to any other civilians and civilian property that will be affected by his attack.

Additionally, the "precautions against the effects of attacks" found in API ${ }^{78}$ must be applied in light of the realities of TAC. This rule applies equally to all parties to the conflict, not just the attacking force. ${ }^{79}$ While it is unlikely that most fighters will comply with Article 58 since they purposely avoid a fixed and distinctive sign in order to avoid being targeted, militaries wishing to comply with the LOAC must be aware that this still applies to TAC environments. Determining which civilian populations are "under their control" may be a key to the application of this principle.

Situations that constitute TAC will vary greatly, causing reasoned adjustments to some LOAC principles as commanders apply well-learned rules to the application of combat power. However, little adjustment will be necessary to the fundamental principles of distinction in targeting and proportionality. Rather, these principles have clearly migrated from the LOAC to both NIAC and TAC.

\section{Humane Treatment: Post-Submission Status Determinations and Conditions of Detention}

The principles addressed thus far operate to regulate the application of combat power. However, as with any armed conflict, regulation of the conduct of belligerents does not end once an opponent is brought to submission. When such submission results in the opponent falling under the control of its enemy, detention and treatment during detention become the critical regulatory concerns. Indeed, the treatment of individuals captured by the U.S. and designated "unlawful enemy combatants"-persons subject to detention as a result of their membership in a transnational armed entity hostile to the U.S. - has been the primary focus of legal debate, judicial intervention, and international criticisms since the U.S. commenced military operations against al Qaeda. As has become both well known and notorious, by defining the armed conflict with al Qaeda as falling into a seam between international and non-international armed conflicts, U.S. policy makers and their legal advisors have asserted that no law

\footnotetext{
${ }^{78} \mathrm{API}$, art. 58.

${ }^{79}$ Geoffrey S. Com, International and Operational Law Notes: Principle 7: Distinction Part II, ARMY L. 35 (June 1999).
} 
operates to protect the interests of these "wartime" detainees, even while asserting the existence of armed conflict as the legal justification for their detention. This episode, perhaps more than any other related to the military component of the Global War on Terror, illustrates why it is so essential to conceptualize such operations as a triggering event for application of LOAC principles. Triggering this law is essential to ensure that when a State invokes the authority of war for the purpose of detaining captured individuals, it will be bound by the baseline standard of treatment that has evolved to protect detainees. This premise was at the heart of the Hamdan decision. This standard is the principle of humane treatment.

Humane treatment is unquestionably a cardinal principle of the LOAC, and the primary "counter-weight" to the authority derived from this body of law. This principle provides the substance to Common Article 3, and is reflected in many other treaty provisions. The centrality of the principle of humane treatment to the Geneva tradition of protecting victims of war is reflected in the ICRC Commentary to Common Article 3:

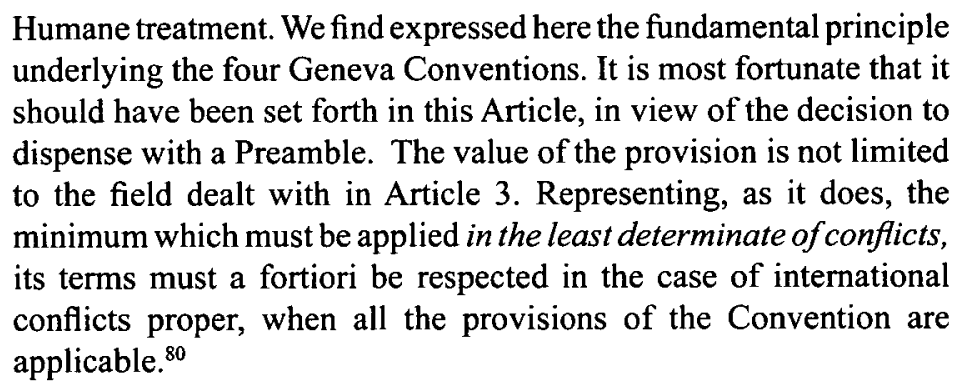

The principle of humane treatment is derived from reference to numerous LOAC treaty provisions applicable across the spectrum of armed conflict ${ }^{81}$ and from the consistent practice of professional armed forces during military operations spanning from non-conflict operations to international armed conflict. ${ }^{82}$ Humane treatment of such individuals is the essential component to respect for the concept of humanitya fundamental principle of law related to military operations. It reflects the basic concept that all individuals, even those who actively oppose friendly armed forces,

\footnotetext{
${ }^{80}$ See GCI COMmentarY, supra note 30, at 52 (emphasis added G.C. \& E.T.J.).

${ }^{81}$ RODGERS, supra note 48, at 48-57.

82 See Com, supra note 24, at 315-20 (discussion policy based application of LOAC principles during contemporary military operations).
} 
are, when no longer capable of manifesting such opposition, entitled to respect as human beings, which in turn is premised on a truism that animates the LOAC: the execution of military operations represents the implementation of national purpose, and is not motivated by personal interests, anger, or revenge.

While the humane treatment mandate for any person who is hors de combat is regarded as a core principle of the LOAC, it is much more difficult to comprehensively define the content of this principle. In some way, the definition of humane treatment is similar to the definition of pornography: "you know it when you see it." Or perhaps it is more accurate to state that you know a violation when you see it. The most basic meaning of humane treatment is that an individual must be treated as a human being, and nothing less. However, the precise meaning of the term "humane" has always been elusive, and more susceptible to a negative than positive definition. This is clearly reflected in the substance of Common Article 3, which states the broad humane treatment mandate, but then uses a non-exclusive list of prohibited acts to define what violates this mandate. This approach to giving meaning to the principle is emphasized in another excerpt from the ICRC Commentary:

Lengthy definition of expressions such as "humane treatment" or "to treat humanely" is unnecessary, as they have entered sufficiently into current parlance to be understood. It would therefore be pointless and even dangerous to try to enumerate things with which a human being must be provided for his normal maintenance as distinct from that of an animal, or to lay down in detail the manner in which one must behave towards him in order to show that one is treating him "humanely", that is to say as a fellow human being and not as a beast or a thing. The details of such treatment may, moreover, vary according to circumstances- particularly the climate-and to what is feasible.

On the other hand, there is less difficulty in enumerating things which are incompatible with humane treatment. That is the method followed in the Convention when it proclaims four absolute prohibitions. The wording adopted could not be more definite: "To this end, the following acts 'are' and 'shall remain prohibited at any time and in any place whatsoever." No possible loophole is left; there can be no excuse, no attenuating circumstances. ${ }^{83}$

${ }^{83} \mathrm{Id}$. at 53. 
Although the Commentary suggests the impracticability of a comprehensive definition of humane treatment, the reference to "treatment like a human being" has tremendous significance. This is particularly true with regard to captured enemy fighters. ${ }^{84}$

Understanding the reality that mortal combat always presents a risk of evoking the darker side of human instinct-instinct that can and often has led to acts of revenge and retribution directed toward captured opponents-is essential to understanding why the simple assertion that humane treatment means treating a former opponent as a human being is so significant. This mandate requires that warriors "restore" to a status of human being opponents who may have been trying to kill the detaining forces only moments prior to capture. This does not necessarily become easier the more attenuated the detainee becomes from the immediate fight. Soldiers who have been trained to vilify the enemy are required to treat that enemy in a fundamentally different manner upon capture and during all phases of detention.

The humane treatment obligation in the context of TAC is triggered when the forces of one of the parties to the conflict gain control over a member of the forces of the opposing Party. At this point, the captured individual is hors de combat. It is almost axiomatic that the humane treatment of an enemy made hors de combat begins with quarter. ${ }^{85}$ Thus, detention of the enemy commences, and conditions of detention then become the critical elements of implementing the humane treatment

${ }^{84}$ Humane treatment operates as a "counter-weight" against the human instinct of revenge or retribution that is so easily evoked by participation in mortal combat. One of the most difficult challenges for any battlefield warrior is to overcome the natural aversion of civilized society to the killing of another human being. Because of this, professional armed forces have long understood that preparing warriors for battle requires the dehumanization of the enemy. An interesting pop culture illustration of this is seen in a movie about the Korean War, "Fixed Bayonets!" During one scene, a young soldier confronts his first opportunity to kill an enemy with direct fire from his riffe. $\mathrm{He}$ is incapable of pulling the trigger, and another soldier must then shoot the enemy. However, his sergeant mistakenly believes that the soldier who froze was actually the one who killed the enemy, and the following dialogue ensues: "[A]ll you gotta remember is that you're not shooting at a man; you're shooting at an enemy. Once you remember this you are over the hump; you are a rifleman." requires dehumanization of the enemy. As brutal as this may sound, it has become a core tenet of military training, particularly in response to empirical studies following World War II which indicated that a large percentage of front line soldiers, like the fictional soldier in this episode, were unable to overcome their aversion to killing and as a result never fired a shot. It is therefore no accident that soldiers train by shooting at "silhouettes" and that the enemy is referred to with negative characterizations.

${ }^{85}$ Denial of quarter could never be justified by necessity as the captured individual is no longer an active participant in hostilities. The prohibition against denial of quarter is encompassed in the specific prohibitions against murder and summary execution contained in Common Article 3 . 
obligation. However, it is important to analyze this obligation based on the differing levels of detention. Common Article 3 Commentary indicates that "[T]he details of such treatment may, moreover, vary according to circumstances-particularly the climate-and to what is feasible." 86 However, here the list of expressed prohibitions contained in Common Article 3 becomes very significant, for they indicate that even at the point of capture, in the midst of intense combat, "circumstances" can never justify abusive treatment of a detainee. This does not, of course, impede the ability of the detaining force to take measures to secure the captured enemy and protect security interests. Accordingly, there is nothing inhumane about following what are known in U.S. military practice as the five "S's": Secure, Search, Segregate, Safeguard, and Speed to the Rear. ${ }^{87}$ Moreover, blindfolding a captured enemy is not considered inhumane, as long as there is a security-based justification. ${ }^{88}$

While Common Article 3 did not specifically address the denial of quarter, the humane treatment article of API does include an express prohibition against denying quarter. See APII, art. 4. This is highly instructive for purposes of TAC because APII addressed treatment obligations protecting captured individuals who would not be entitled to any special status, such as that of prisoner of war. The ICRC Commentary to APII explains the express inclusion of the prohibition as a component of humane treatment:

The rule on quarter

This is one of the fundamental rules on the conduct of combatants inspired by Hague law. It is aimed at protecting combatants when they fall into the hands of the adversary by prohibiting a refusal to save their lives if they surrender or are captured, or a decision to exterminate them. The text of the draft was more explicit and read as follows: "It is forbidden to order that there shall be no survivors, to threaten an adversary therewith and to conduct hostilities on such basis." The present wording is briefer, but does not alter the essential content of the rule. Clearly respect for this rule is fundamental. It is a precondition governing the application of all the rules of protection laid down in the Protocol, for any guarantees of humane treatment, any rule on care to be given the wounded and sick, and any judicial guarantees would remain a dead letter if the struggle were conducted on the basis of orders to exterminate the enemy.

The inclusion of this provision amongst the fundamental guarantees laid down in Article 4 is of special importance. In fact, it indirectly indicates the moment from which combatants who are no longer able to fight are protected by Part II, a function originally assigned in the draft to the rule on safeguarding enemies 'hors de combat'. Protection of enemies 'hors de combat' is in a way the final stage of the present rule on quarter, in the sense that the prohibition against ordering that there will be no survivors affects the concept of military operations even before the enemy is 'hors de combat.'

See Protocol I \& II Commentary, supra note 71, at 1371.

${ }^{86}$ GCI COMMENTARY, supra note 30 , at 53.

${ }^{87}$ U.S. Dep't of Army, Field Manual 5-170, Engineer Reconnaissance 7-11 (July 1998).

${ }^{88}$ The creation of the detainee category of "unlawful enemy combatant" was unfortunately used at certain points in time as a basis to "manipulate" the humane treatment standard. This is clearly 
As the detainee progresses from the point of initial capture to long-term detention facilities, the treatment standards should become more "mature" and less ad hoc. ${ }^{89}$ Additional concerns arise at the established detention facility level. While the humane treatment obligation does not result in the conclusion that detainees are to be treated analogously to individuals afforded special protections, such as prisoners of war, (POW) some fundamental aspects of POW treatment do seem to fall under the rubric of humane treatment in TAC. These include first and foremost the provision of basic needs of human existence: adequate food, shelter, clothing, and medical care. In addition, the right to free exercise of religion, respect for religious and cultural meal preferences, and access to impartial humanitarian relief agencies also should fall within the definition of humane treatment. All of these elements of the humane treatment of detainees are expressly provided for by APII. While this treaty does not apply to TAC, it nonetheless provides important insight into the established minimum standard of detainee treatment. ${ }^{90}$

There are, however, several other analogies to the required treatment of POWs that would arguable fall under the humane treatment mandate. The most obvious, yet still controversial, of these is the obligation to provide notice to some third Party of the fact of detention. For POWs, this is a critical obligation, for this notice requires ultimate accountability for the POW by the detaining power. Because of this effect, this requirement provides perhaps the most meaningful safeguard against abusive treatment or even execution of POWs. It is therefore clear that providing analogous

reflected in the President Bush's February 2002 memorandum where he indicates that captured al Qaeda operatives are entitled to humane treatment as a matter of "policy" and subject to the dictates of military necessity. However, the basic components of the humane treatment obligation come into force not as a matter of policy, but as a matter of law in the context of TAC.

${ }^{89}$ Acknowledging the indelible nature of the specific prohibitions of Common Article 3 does not, however, resolve every question regarding detainee treatment. The combat environment is one of extreme uncertainty, and even the most comprehensive detainee treatment doctrine is susceptible to this uncertainty. However, as a general proposition, the humane treatment obligation can be effectively implemented by building detainee treatment on a three pillar foundation. The first pillar is to ensure detaining forces recognize that once hors de combat, an enemy is no longer the permissible object of hostility. The second pillar is to comply with the express prohibitions contained in Common Article 3. The final pillar is to ensure that at a minimum, conditions for detainees are never worse than those for the detaining forces. This last pillar is the essential solution to the variables of the combat environment, for it ensures that "situational" application of the humane treatment mandate is linked to a standard of reasonableness. For example, if rations are in short supply, they will be shared equally by detaining and detained forces; medical treatment will always be based on principles of triage applied equally to detaining and detained personnel; the shelter provided for detainees will mirror that provided for detaining forces, and so on.

${ }^{90} \mathrm{See}$ APII, art. 5. 
notice to the State of nationality or to the ICRC of the detention of detainees who are not entitled to special status provides an equally critical safeguard against maltreatment. Such notice provides the detainee with some minimal sense of protection derived from outside concern, and sends a powerful signal to both the detainee and the detaining power that there will be ultimate accountability for the whereabouts and the treatment of the detainee. The extent of access to communicate with third parties is more problematic, but barring some imperative security concern, there seems to be little justification for excluding such access from the scope of the obligation.

Three detention issues where the meaning and effect of humane treatment have been particularly difficult to determine have been the basis for detention, duration of detention and procedures for subjecting detainees to criminal sanction for pre-or post-detention misconduct. Both of these issues have been the subject of extensive debate and litigation in relation to al Qaeda detainees held by the United States. While there is general consensus that both these issues are impacted by the humane treatment obligation, what is specifically required is far more difficult to ascertain. At a minimum, however, certain limits seem clear. With regard to the basis for detention, it seems that detention must only be based on the legitimate military necessity of preventing an enemy from returning to the fight. In this regard, there is a clear link between the principles of military necessity and humane treatment: military necessity provides the legal justification for detention; humane treatment prohibits detention for any reason falling outside that justification..$^{91}$ Humane treatment also ostensibly requires some minimum notice, opportunity to be heard, and periodic review of the decision to detain. These measures are necessary to ensure that detention is genuinely initiated and continued based on the need to keep the detainee from returning to the fight.

The duration of detention is closely related to the initial justification for detention. Subjecting an individual to indefinite detention with no determination of a genuine and/or continuing justification is itself arguably inhumane, a conclusion bolstered by the fact that virtually all contemporary detention operations during non-conflict

${ }^{91}$ Of course, there is always a possibility that an individual detainee may be subject to criminal sanction for his or her pre-capture conduct. While the humane treatment obligation in relation to such sanction implicates procedural fairness concerns, once an individual has been sentenced to a period of confinement as a criminal sanction the basis for detention shifts from preventive to penal. So long as procedures used during the criminal process meet minimum standards of fundamental faimess, and conditions of penal confinement comport with the humane treatment obligation, penal detention comports with the obligation. 
operations or non-international armed conflicts have been based on minimal procedural safeguards. In the context of an international armed conflict, prisoners of war are entitled to repatriation at the close of hostilities. Such an entitlement also seems logically applicable to individuals detained during the course of a noninternational armed conflict. The difficulty in this context is identifying the point of such termination. This is particularly problematic in the realm of TAC; conflicts which the U.S. Supreme Court has recognized could very well be "generational" in duration. ${ }^{92}$

Accordingly, an alternative mechanism is necessary to ensure that the inability to define a termination point to hostilities with transnational terrorist organizations does not become a justification for indefinite arbitrary detention. That mechanism is a periodic review procedure designed to assess whether a detainee continues to pose a threat of return to hostilities. No analogous mechanism exists for POWS, because POW status establishes a conclusive presumption of such a threat for the duration of hostilities, and there is some assumption of a reciprocal interest in POW exchange. In this regard, the contemporary practices of the Unites States that provide for annual review for all detainees - a process implemented without any judicial prodding and patterned after the process laid out in GCIV - is an indication of the type of alternative methodology required to ensure that the duration of detention does not become inhumane by becoming arbitrary.

The question of what procedural safeguards for criminal prosecution are required by the humane treatment obligation is equally challenging. Indeed, the uncertainty associated with this question was central to the U.S. Supreme Court decision in Hamdan. While that challenge involved the limited question of the right to be present during proceedings, the Court's emphasis on the "fair and regularly constituted tribunal" requirement of Common Article 3 provided some clarification to this question. $^{93}$ Again, while the periphery of this issue may remain obscure, the core requirement is that detainees be protected from any adjudication that is not the result of a process that can ensure the basic requirements of a fair trial. While Common Article 3 uses a generalized expression of this obligation, both Additional Protocols provide a much more comprehensive articulation of the components of a "fair and regularly constituted tribunal." This fact was not lost on the Hamdan plurality, at least with regard to API. ${ }^{94}$ The provision of that treaty providing for minimum guarantees

\footnotetext{
${ }^{92}$ Boumediene v. Bush, 128 S. Ct. 2229, 2238 (2008).

${ }_{93}$ Hamdan v. Rumsfeld, supra note 1, at 630.

${ }^{94} I d$. at 633 .
} 
for any person not otherwise protected by a more specific treaty provision was relied on by the plurality to bolster the argument that the military commission procedures violated the humane treatment obligation. ${ }^{95}$

While the Court relied on Article 75 of API, it is worth noting that APII includes an identical fundamental guarantee provision intended to establish humane treatment procedural trial standards: Article 6. What seems particularly compelling about the inclusion of "Article 75" type trial guarantees in APII is that this treaty was developed to apply to internal efforts to overthrow the authority of a government. Because such conflicts represent perhaps the most significant challenge to the sovereign authority of the State, the imposition of these procedural protections for a defendant is a powerful indication that they are central to the concept of humane treatment. It is also an indication that the States that negotiated APII did not believe affording these protections would compromise the ability to hold individuals accountable for violations of the law of war.

The relationship between Article 6 of AP II and the principle of humane treatment reflected in Common Article 3-the principle integral to the opinion of the Court that the military commission procedures violated their constitutive law-simply bolsters the conclusion of the plurality. As the ICRC Commentary notes, humane treatment requires that criminal defendants associated with all conflicts be afforded basic procedural guarantees.

${ }^{95}$ Id. at 634-35. Article 75 of API is best understood as an express extension of the Common Article 3 humane treatment mandate to international armed conflicts. See Protocol I \& II COMmENTARY, supra note 71 , at 861 . It expanded the non-exclusive list of requirements derived from the humane treatment obligation. This inherent relationship between Common Article 3 and Article 75 explains why a plurality of the Court would look to Article 75 to illuminate the meaning of Common Article 3. What seemed even more significant to the plurality was the more extensive treatment by Article 75 of the "regularly constituted" tribunal aspect of the humane treatment mandate. See Hamdan v. Rumsfeld, supra note 1, at 634-35. Article 75 amplifies extensively the meaning of a "humane" adjudication of alleged criminal misconduct, and in particular the right of a defendant to be present during the trial.

APII includes an almost identical articulation of the components of a fair and regularly constituted tribunal. Indeed, because this treaty was not only created to regulate non-international armed conflicts, but has unlike API never been explicitly rejected as "fatally flawed" by the United States, it is somewhat inexplicable why the Hamdan plurality did not rely on it in conjunction with or in lieu of API. More importantly for purposes of this analysis, consideration of APII as a source of the definition for the principle of humane treatment points to the same conclusion as the analysis of Article 75. Like API, APII also includes "fundamental guarantee" provisions that address the implementation of the humane treatment mandate vis-à-vis criminal adjudications. Unlike API, the protections afforded to individuals subject to prosecution by APII are contained in a distinct article, Article 6, titled "Penal Prosecutions." 
The whole of Part II (Humane treatment) is aimed at ensuring respect for the elementary rights of the human person in non-international armed conflicts. Judicial guarantees play a particularly important role, since every human being is entitled to a fair and regular trial, whatever the circumstances; ...

The text repeats paragraph 1, sub-paragraph (1)(d) of Common Article 3, with a slight modification. The term "regularly constituted court" is replaced by "a court offering the essential guarantees of independence and impartiality". In fact, some experts argued that it was unlikely that a court could be "regularly constituted" under national law by an insurgent party. Bearing these remarks in mind, the ICRC proposed an equivalent formula taken from Article 84 of the Third Convention, which was accepted without opposition.

This sentence reaffirms the principle that anyone accused of having committed an offence related to the conflict is entitled to a fair trial. This right can only be effective if the judgment is given by " $a$ court offering the essential guarantees of independence and impartiality. ${ }^{96}$

The language from the Commentary dispels any doubt as to the centrality of a regularly constituted tribunal to the concept of fundamentally fair justice and, accordingly, compliance with the principle of humane treatment. Of particular relevance is Article 6's apparent contemplation of the use of military commissions.

Just like Common Article 3, Additional Protocol II leaves intact the right of the established authorities to prosecute, try and convict members of the armed forces and civilians who may have committed an offence related to the armed conflict; however, such a situation often entails the suspension of constitutional guarantees, the promulgation of special laws and the creation of special jurisdictions. Article 6 lays down some principles of universal application which every responsibly organized body must, and can, respect ... ${ }^{97}$

Thus, it seems that even when resort is made to "special" tribunals or jurisdictions to deal with violations of the law during an armed conflict (such as the creation of the military commissions), procedural legitimacy remains the sine qua non of

\footnotetext{
${ }^{96} \mathrm{Id}$. at 1396-97 (emphasis added G.C. \& E.T.J.).

${ }^{97}$ Id. (emphasis added G.C. \& E.T.J.).
} 
compliance with the principle of humane treatment. Article 6 should therefore serve as a compelling indication that these considerations cannot justify deviation from the minimal procedural protections, and that these protections are essential components of the humane treatment obligation applicable to all armed conflicts.

\section{CONClusion}

Transnational armed conflicts have become a reality. The increasing sophistication of terrorist organizations, to include the development of military strike capabilities, is and will continue to push States to resort to combat power as a means to defend against this threat. Perhaps more importantly in relation to the thesis of this Article, the increasingly transnational nature of such terrorist organizations and the operations they conduct will continue to force States to employ that combat power beyond their national borders against these non-State entities. Recent examples involving U.S. operations against al Qaeda, Israeli operations against Hezbollah, Turkish operations against the PKK in Iraq, and Colombian operations against the FARC all serve as a testament to this reality. Relying on the factual fiction that the acts of such terrorists must be attributable to the States from which they launch their operations, or on the legal fiction that the use of military combat power to respond to such threats is in reality just extraterritorial law enforcement, fails to acknowledge the essential nature of such operations. Because these operations involve the inherent invocation of the authority of the LOAC, they should and must be treated as armed conflicts.

If acknowledged that certain uses of military power to respond to threats posed by non-State transnational enemies fall into the category of armed conflict, it becomes essential to ensure that a "package" of regulatory principles applies to such operations. This "package" concept is necessary to ensure that the fundamental balance between authority and obligations that lies at the core of the LOAC is preserved, and that States are prevented from invoking the authority of "war" without accepting the complimentary obligations; a conception of the LOAC at the heart of the Hamdan decision.

Recognizing that the LOAC should be applied to TAC is, however, only the first step in the analytical process of providing an effective regulatory framework for such operations. What is necessary is to begin the process of defining the rules that regulate such conflicts, a process that must mirror the process that has so effectively defined the body of norms that regulate internal armed conflicts. Like that process, the first step is to identify those LOAC principles that provide the regulatory foundation. These principles must be broad enough to provide the authority necessary to accomplish the 
task of bringing the transnational enemy to submission, while also ensuring that that authority is not permitted to effectively override fundamental humanitarian protections for the victims of war.

This Article proposes that the three essential pillars of this regulatory foundation are the principles of military necessity, targeting (object/distinction and proportionality), and humane treatment. These principles lie at the core of the LOAC, and provide the balance between authority and obligation that is so essential for the effective and disciplined application of combat power. However, this must be a first step in a much more complex process of evolution. Like the treatment of internal armed conflict, these pillars can form a foundation for a more comprehensive treatment of regulatory analysis, a treatment that might include other issues such as command responsibility, criminal liability, treatment of property, access to judicial review, perfidy and treachery, and medical obligations. But every journey must begin with a proverbial first step, and that first step in the realm of regulating transnational armed conflict begins with the principles proposed herein. 